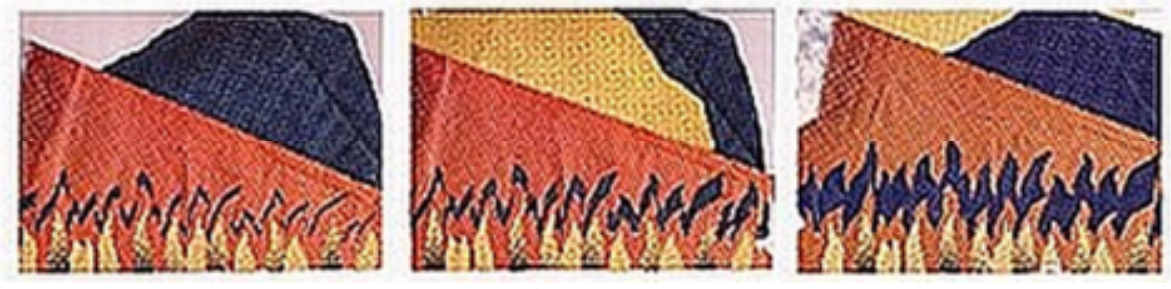

Ilustração Taís Noronha Tourinho

\title{
É com o capeta!
}

\section{Flávio Barão}

Flávio Barão é jornalista, radialista e compositor. É autor do livro A Obra, que inclui 70 crônicas e contos, dentre eles, "É com o capeta". Através da Barão Assessoria \& Comunicação Ltda, edita jornais, revistas e desenvolve projetos promocionais para empresas e entidades.

Como bimbado, gestado e criado no interior, comecei minha "carreira" de jogador de futebol na roça. Era uma festa. E os festivais, então? A turma empoleirava na carroceria do caminhão, começo da tarde, num sol de rachar, e seguia para um dos povoados da região. A viagem, geralmente, era por estrada de terra, cheia de costelas. Sacudia tanto que misturava a comida do almoço com aquela "comida" que já estava ali há algum tempo. E quando chovia? Era aquela farra, uma mistura de frio, barro e alegria, com a volta (às vezes, também, a ida) regada a cachaça. Numa dessas, fomos jogar nos Machado. (Os povoados, em geral, recebem como nomes os sobrenomes da familia mais importante do local). Uma chuva de lascar. 0 caminhão, um Mercedes 1113, acostumado a carregar leite, perdeu o freio na volta. O motorista, tão chumbado quanto nós todos, segurava o bruto na marcha. E nós ali, cantando e bebendo, sem imaginar o aperto. Conseguimos voltar para casa inteiros, depois de duas freadas no barranco e de atropelarmos algumas árvores.

São muitas histórias, jogos memoráveis e personagens ilustres. Como um zagueiro do cascudo das "Bernardas" (o distrito é dos Bernardes), que atuou com uma faca na meia; ou o torcedor dos Souza, todo de branco na beirada do barranco. Parecia o Benito de Paula, com suas melenas fartas e um bigodão lusitano. Meu time ganhava de um a zero, já no final da partida, quando o 
"Benito" sacou 038 e sapecou dois tiros pra cima. Eu sumi no meio das taiobas e só voltei uns 20 minutos depois, com o jogo empatado em um a um.

Mas a história que realmente marcou foi num torneio rural, disputadíssimo, no qual eu ainda era torcedor. Como todo bom torneio rural, as finais seriam disputadas na cidade, num campo gramado e com juiz (só um) da liga mais próxima. O time da minha preferência era a Cachoeira, de uniforme verde e preto, igual ao América de antigamente. A partida era contra os Costas, arqui-rival, que sempre ganhava.

Consegui entrar no vestiário da Cachoeira pouco antes do início da partida, através de um primo e amigo, que atuava de lateral esquerdo improvisado. O clima estava tenso. Só a vitória interessava. Nas cinco últimas partidas, um empate e quatro derrotas. A turma molhava a cabeça de minuto em minuto, para compensar a falta do córrego. Tinha até fila para usar o vaso.

Quase na hora do jogo, o treineiro distribuiu as camisas e partiu para a preleção. Pediu para a defesa segurar lá atrás, - meio campo tocar a bola e o ataque fazer gol. Todos assimilaram as orientações e, quando já iam subindo para o campo, o capitão do time falou: - Vamos rezar um Pai Nosso e uma Ave Maria pra gente entrar em campo com a força do Senhor.

E o treineiro rebateu:

Senhor o escambau. Hoje nós vamos entrar é com o Capeta. A gente reza todo jogo e só leva tinta. Hoje não tem reza coisa nenhuma. Nós vamos jogar é com o Capeta.

E a turma da Cachoeira subiu para o campo gritando: É o Capeta! É o Capeta! É O Capeta! Desde aquele dia, passei a acreditar que o futebol era mágico, fantástico, extraterrestre. A Cachoeira ganhou de dois a um. Após o jogo, no vestiário, uma alegria sem igual. Para comemorar, todos se abraçaram e o treineiro puxou uma Salve Rainha para agradecer. 